\title{
Problem osobnog identiteta u filozofiji Davida Humea
}

\author{
Stipe Buzar*
}

\begin{abstract}
Sažetak
Autor tematizira problem osobnog identiteta u filozofiji Davida Humea. U tekstu su najprije predstavljeni elementi Humeove teorije ideja koji su nužni kao kontekst za razumijevanje njegova tretmana problema osobnog identiteta. $U$ drugom dijelu autor opisuje Humeov pristup osobnomu identitetu, pri čemu se obraduje adekvatno poglavlje iz Humeove Rasprave o ljudskoj naravi. Nakon toga nude se pogledi nekih od najcitiranijih Humeovih komentatora, da bi se proširilo razumijevanje određenih vidika Humeova problema te pokazali neki od nedostataka njegova pristupa.

Ključne riječi: David Hume, osobni identitet, empirizam, percepcije, impresije, ideje, supstancija
\end{abstract}

\section{Uvod}

David Hume (1711. — 1776.) bio je škotski empiristički filozof i povjesničar koji je svojim pisanim djelima zadužio svijet znanosti i mišljenja, a napose onaj filozofski. Iako značajniju literarnu slavu svojih filozofskih radova nije doživio za života, barem kada je riječ o njegovu najznačajnijem djelu $A$ Treatise of Human Nature (1738.-1740., Rasprava o ljudskoj naravi), ${ }^{1}$ neki njegovi filozofski nazori snažno odjekuju među velikim misliocima poput Immanuela Kanta, Bertranda Russella, a napose čitave plejade analitičkih filozofa na područjima kao što su primjerice ontologija, filozofija uma, epistemologija, filozofije religija, etika. Pokušavajući objasniti Humeovu popularnost, Bertrand Russell istaknuo je da se opširnost citiranja Humea u britanskoj filozofiji može pripisati već eleganciji nje-

* Dr. sc. Stipe Buzar, DIU LIBERTAS Međunarodno sveučilište. Adresa: Trg J. F. Kennedyja 6b, 10000 Zagreb, Hrvatska. E-pošta: sbuzar@libertas.hr

1 Prilikom pisanja rada koristili smo se aktualnim kritičkim izdanjem: Hume, 1979. Na Humeovu Raspravu referirali smo se uobičajenim načinom u radovima njegovih komentatora: kraticom $\mathrm{T}$ i brojem stranice, primjerice (T 314). Na Dodatak u istom izdanju referira se kraticom A i brojem stranice, primjerice (A 636). U citatima donosimo vlastiti prijevod tekstova. 
gova stila, koji je narednim generacijama autora uvijek služila kao izvor, ali čiju ljepotu nitko od njih nije dostigao (Russell, 2005).

Humeovo literarno djelovanje daleko je šire od njegova filozofskog djelovanja, a u filozofiji je uspio obraditi većinu relevantnih problema svojeg vremena. Jedan od njih tiče se temeljne naravi osobnog identiteta, vlastitog ,ja“. Humea zanima postoji li neko ,ja“ kao temelj osobnog identiteta. Koja je uopće narav osobnog identiteta?

Hume se problemom osobnog identiteta bavi na razmjerno malom broju stranica, no nije ga moguće shvatiti bez poznavanja ranije razložene teorije ideja. Stoga ce plan izlaganja u ovom tekstu biti sljedeći: Prvo, ukratko će se obraditi Humeova teorija ideja kako bi se problemu osobnog identiteta pružio širi kontekst u Humeovoj filozofiji. Drugo, analizirat će se slavan Humeov odjeljak iz prve knjige Rasprave u kojem se taj sud donosi. Treće, uzet će se u obzir nekolicina eminentnih Humeovih komentatora da bi se razjasnili neki detalji njegova pristupa. Četvrto, zaključno će se izložiti vlastito mišljenje o Humeovu pristupu.

\section{Humeova teorija ideja}

Humeova teorija ideja nalazi se na samom početku Rasprave, a predstavlja temelj njegova filozofiranja. ${ }^{2}$ Prije Humea, teoriju ideja razvili su John Locke (Locke, 1995) i George Berkeley (Berkeley, 2003), na čijim se teorijama uvelike temeljila i Humeova teorija ideja. Hume na svoju teoriju vjerojatno uopće nije gledao kao na teoriju. Ona je za njega predstavljala neupitnu istinu o ljudskom umu te je nikada nije pokušao opravdati argumentima, a detaljno izlaže samo ono za što smatra da će mu biti od koristi kasnije (Stroud, 2003, 17). Za detaljniji prikaz teorije ideja potrebno je vratiti se Lockeu. On idejama naziva sve što je objekt razuma kada čovjek razmišlja. Svaka misao ili razmišljanje jednako je posjedovanju neke ideje. Još ostaje pitanje odakle te ideje. Lockeov je odgovor, s kojim se Hume potpuno slaže, iskustvo. Utoliko je iskustvo temelj mišljenja i znanja. No, ne dolaze sve ideje neposredno iz iskustva. Postoje tzv. ideje senzacije, koje dolaze neposredno preko naših osjetilnih organa, i ideje refleksije, koje su rezultat mišljenja, tj. miješanja ideja u našem umu (Stroud, 2003, 18).

Hume, s druge strane, sve predmete našeg uma ne naziva idejama, nego percepcijama. ${ }^{3}$ Percepcije dijeli na: impresije i ideje.

Razlika između tih dvaju predmeta uma je u »stupnjevima [njihove] snage i živosti, kojima se javljaju u umu, i kojima ulaze u naše mišljenje ili svijest « (T 1). One percepcije koje u našu svijest ulaze s najviše snage Hume naziva impresijama te pod njih podvodi sve naše senzacije, strasti i emocije, onako kako se one prvi

2 Svoju teoriju ideja Hume razvija u prvoj knjizi Rasprave naslovljenoj Of the Understanding (O razumu), u prvom dijelu pod naslovom Of ideas, their origin, composition, connexion, abstraction, etc. (O idejama, njihovu porijeklu, kompoziciji, povezanosti, apstrakciji itd.).

3 Hume je uvjeren da je Locke iskrivio izvorno značenje termina ideja (T 2). 
put pojavljuju u duši (usp. T 1). ${ }^{4}$ Ideje su, pak, blijede slike impresija u mišljenju i zaključivanju. Kao što je već navedeno, Hume tu podjelu smatra potpuno prirodnom i ne vidi razloge za njezino podrobnije argumentiranje. Zadovoljava se izjavom da svi vrlo lako mogu uočiti razliku između vlastitog osjećanja i mišljenja. Doduše, pristaje na mogućnost da postoje slučajevi u kojima nam se ideje mogu učiniti impresijama. To su, primjerice, slučajevi sna, groznice, ludila i drugih nasilnih događaja u duši. Također, postoje slučajevi kada nam impresije izgledaju kao ideje, ukoliko se iz nekog razloga javljaju u tako slabašnom obliku da ih je teško odijeliti od ideja. No, izuzimajući takve iznimne slučajeve, impresije i ideje lako je razlikovati, a upravo zato ih i dijelimo u navedene kategorije (usp. T 2).

Još jedna podjela među našim percepcijama koja se proteže na impresije i ideje je između: složenih (complex) percepcija i jednostavnih (simple) percepcija.

O njima je Hume zapisao sljedeće: »Jednostavne percepcije ili impresije i ideje takve su da ne priznaju nikakvo razlikovanje ni dijeljenje. Složene su njima suprotne te možemo razlikovati njihove dijelove« (T 2). Složena je, dakle, impresija ili ideja konstruirana od dvije ili više impresija ili ideja. Hume kao primjer navodi impresiju ili ideju jabuke, koja je za nas složena od određenih svojstava okusa, boje i mirisa te smo u stanju ta svojstva u našoj duši razdvojiti i prepoznati kao zasebna, bez obzira na činjenicu da su sva ujedinjena u našoj percepciji jabuke (usp. T 2).

Nakon što je naznačio razliku između složenih i jednostavnih percepcija, Hume želi nešto dublje ispitati odnos impresija i ideja. Prva stvar koja se čini očitom u njihovu odnosu je da su jako slične u svakom pogledu, osim u snazi i živosti kojima se predstavljaju umu. Na prvi pogled čini se da ideja X savršeno reflektira impresiju X u svakom slučaju (i obrnuto) te da su sve percepcije uma dvostruke, pojavljujući se i kao impresije i kao ideje (usp. T 2-3). No, ako uzmemo u obzir razlikovanje između jednostavnih i složenih ideja, vidimo da je ta dvostrukost percepcija ograničena na samo jedan njihov dio. Možemo lako primijetiti da brojne naše složene ideje ne vuku porijeklo iz neke složene impresije te brojne naše kompleksne impresije nikada ne bivaju točno preslikane u idejama. U prvom slučaju Hume navodi primjer biblijskog Novog Jeruzalema, čiju složenu ideju posjedujemo na temelju opisa iz Knjige Otkrivenja, ali čiju impresiju nikada nismo dobili. U drugom slučaju možemo zamisliti mjesto koje smo zaista vidjeli i čiju impresiju imamo, primjerice Svetojurski Vrh u Hrvatskom zagorju, ali ne možemo sa sigurnošću reći da možemo formirati složenu ideju tog mjesta koja bi savršeno reprezentirala ulice i kuće tog mjesta u njihovim stvarnim proporcijama (usp. T 3). Dakle, kada je riječ o sličnosti složenih impresija i ideja, možemo reći da nije univerzalno točno reći da je riječ o preciznoj reprezentaciji.

Sljedećem obilježju u odnosu impresija i ideja treba posvetiti posebnu pozornost, jer je najdublje povezana s Humeovim zaključcima o osobnom identitetu.

4 Unatoč svojoj anti-supstancijalnoj, a svakako anti-kartezijanskoj teoriji osobnog identiteta, Hume, u nedostatku vokabulara koji bi više pogodovao njegovu pristupu, opetovano koristi nazive $d u s ̌ a, d u h, u m$. 
Kada je riječ o jednostavnim percepcijama, Hume je potpuno uvjeren da pravilo koje ne vrijedi u slučaju složenih percepcija, u ovom slučaju itekako vrijedi. Naime, sve jednostavne impresije imaju točno korespondentne ideje i obrnuto. Način kojim se razlikuju tiče se isključivo stupnja njihove živosti, ali ne i njihove naravi. Primjerice, ideja crvene boje koju prizivamo u misli kada smo u mraku korespondira u svemu savršeno, osim u stupnju živosti, impresiji crvene boje koju vidimo na svjetlu (usp. T 3). Isto vrijedi za sve naše jednostavne ideje i impresije, iako je to nemoguće dokazati nabrajanjem pojedinačnih slučajeva. No, ako bi itko htio negirati tu univerzalnu sličnost među njima, Hume ga poziva da pronađe bilo koju jednostavnu ideju koja nema sebi korespondirajuću impresiju ili, pak, jednostavnu impresiju koja nema savršeno korespondirajuću ideju. Ako to nije u stanju učiniti, slobodni smo podržati doneseni zaključak. Čini se da Hume u tom slučaju umjesto verifikacionističkog pristupa bira metodu falsifikacije, i to u potpunoj sigurnosti da će njegova tvrdnja tom pokušaju opovrgavanja odoljeti. Naznačimo da to ne iznenađuje s obzirom na Humeovu skepsu prema induktivnom postupku. Konačni zaključak koji Hume donosi je da su »sve naše jednostavne ideje kako se prvi put pojavljuju izvedene iz jednostavnih impresija, koje im korespondiraju, i koje one točno reprezentiraju « (T 4). Dakle, prioritet u spoznajnom procesu imaju impresije, koje uvijek nastupaju prije prve pojave neke ideje, a nikada obrnuto. Jednostavne su impresije uzrok (neposredan ili posredan) jednostavnih ideja. To dokazuje jednostavnim primjerima. Primjerice, osoba koja nikada nije vidjela crvenu boju ili okusila ananas ne može imati njihovu ideju, jer nema njihovu impresiju.

Konačno, Hume razlikuje impresije senzacije i impresije refleksije (usp. T 7). Prethodne su rezultat vanjskih podražaja, a potonje su rezultat refleksije, tj. introspekcije ili bilo kojeg drugog unutrašnjeg čina duha. Pravila koja općenito vrijede u odnosu impresija i ideja vrijede i u tom slučaju, tako da postoje i ideje izvedene iz impresija senzacije i refleksije.

\section{Hume o osobnom identitetu}

Poglavlje o osobnom identitetu Hume započinje tvrdnjom da postoje filozofi koji umišljaju da smo u svakom trenutku intimno svjesni onog što zovemo svojim jastvom te tvrdnjom da konstantno osjećamo neprekinuto postojanje jastva u vremenu. Isti filozofi uvjereni su, i to bez demonstriranog dokaza, da je taj entitet savršeno identičan i jednostavan (T 251). Nije, doduše, riječ o tome da neki filozofi taj stav nisu pokušali dokazati, nego o tome da njihove osnovne premise nisu bile strogo temeljene na osjetilnom opažanju. Stoga se takva ideja jastva, sa svojstvima identiteta i jednostavnosti, protivi našemu iskustvu. Da bi na to ukazao, Hume pita sljedeće: »Iz koje impresije bi ova ideja mogla biti izvedena? « (T 251). Nastavlja tvrdeći da mora biti riječ o nekoj jednoj i jednostavnoj impresiji na kojoj se takva ideja temelji. Obratimo se direktno njegovu tekstu:

»Ali jastvo ili osoba nije nijedna jedinstvena impresija, nego ono prema čemu bi nekolicina naših impresija i ideja trebalo imati referenciju. Ukoliko ijedna 
impresija daje ideju jastva, tada ta impresija mora postojati nepromijenjeno jednaka kroz čitav tijek naših života« (T 251).

Kako bi te tvrdnje bile jasnije, prisjetimo se da Hume kaže kako je odnos impresija i ideja takav da svaka jednostavna impresija daje jednu jednostavnu ideju. U slučaju jastva nije uvjeren da je to slučaj. Kao što vidimo, uvjeren je da naša ideja jastva proizlazi iz više različitih impresija. Ako je to tako, onda je ideja jastva kao jednostavnog i savršeno identičnog entiteta u vremenu neispravna, tj. ne bi mogla postojati kao stvarna ideja, nego kao fiktivni entitet. Ako bismo pak htjeli dokazati da takav entitet postoji, morali bismo pronaći impresiju koja odgovara njegovoj ideji.

No, nastavlja Hume, naše impresije, poput bola i užitka, žalosti i radosti, nikada ne postoje istovremeno, zbog čega ne možemo reći da je ta ideja izvedena iz neke od njih (T 252). Zašto bi to bilo problematično? Nismo li naviknuli misliti da svaka senzacija ukazuje upravo na činjenicu da neko »ja« doživljava tu senzaciju. Nije li razumno misliti da svaka promjena mora biti promjena »nečega «, kao što su rast ili opadanje kose promjene koje se događaju nekoj konkretnoj osobi koja, iako promijenjena, nije postala neka druga osoba. Humeov razlog vidljiv je u sljedećim rečenicama:

Što se mene tiče, kada god na intiman način uđem u ono što nazivam svojom osobom, uvijek se spotaknem o neku zasebnu percepciju, vrućine ili hladnoće, svjetla ili sjene, ljubavi ili mržnje, bola ili užitka. Ni u jednom trenutku ne mogu uloviti sebe bez neke percepcije, a nikada ne mogu opažati išta drugo osim te percepcije. Kada su moje percepcije odstranjene na bilo koje vrijeme, kao što je pri duboku snu, toliko dugo sam nesvjestan sebe te se zaista može reći da ne postojim (T 252).

Ne možemo, dakle, u introspekciji nikada naći neku pojedinačnu impresiju koja bi, kada odstranimo sve ostale impresije iz svijesti, ostala. Tek takva impresija predstavljala bi impresiju jastva koja bi bila jednostavna i na kojoj bi se temeljila ideja jastva, koja bi također bila jednostavna. No, uvijek postoji samo neka druga impresija, a kada bi ona bila (i kada jest, kao što Hume kaže, u duboku snu) odstranjena, ne bi ostalo ništa. Što je onda čovjek? Hume o čitavu čovječanstvu nepokolebljivo tvrdi da nije »ništa više nego svežanj ili nakupina različitih percepcija koje se smjenjuju nepojmljivom brzinom te su u stanju neprekinute mijene i pokreta « (T 252). Pokušajmo u tom kontekstu zamisliti razgovor između dva pojedinca, recimo Ludwiga i Ivana. Ludwig bi Ivana mogao upitati što je on točno, a Ivan bi mogao odgovoriti da je on jedan svežanj percepcija. Taj svežanj, doduše, nikada nije isti, nego se svake sekunde bitno mijenja. Budući da je svežanj, znači da je sastavljen, pa se ni u kojem trenutku ne može reći da je utemeljen na nekom jednostavnom entitetu. Budući da je tako sastavljen, ne može se tvrditi da je $u$ trenutku $\mathrm{t}^{1}$ i trenutku $\mathrm{t}^{2}$ identičan, jer se promijenio kvalitativno, što u okvirima Humeove teorije znači da se promijenio i numerički. Svežanj kojemu u jednom trenutku pridijevamo ime Ivan, u drugom nije više taj isti svežanj.

Hume nadalje tvrdi da posjedujemo jednu odjelitu ideju nekog predmeta koji ostaje nepromijenjen i neprekinut tijekom našeg pretpostavljenog vremenskog 
perioda, a tu ideju zovemo idejom identiteta (identity) ili istosti (sameness). Također, imamo ideju nekolicine različitih predmeta koji su tijekom vremena usko povezani, a tu ideju nazivamo idejom različitosti (diversity) (T 253). No, iako su te dvije ideje potpuno različite, a Hume smatra da su protivne, naš uobičajeni način mišljenja često će ih pomiješati. Hume tvrdi da to činimo zato što su djelovanja naše imaginacije (ili uma), kojima razmatramo različite vrste ideja, na neki način jednaka u našem osjećaju. Što to znači, prilično je precizno određeno u sljedeće dvije rečenice:

Ta relacija [bliskosti među različitim predmetima uma] omogućava prijelaz uma s jednog predmeta na drugi te čini njegov prijelaz toliko glatkim, kao da je kontemplirao jedan neprekinuti predmet. Ta sličnost uzrok je te zbunjenosti i greške, čime nas tjera da zamijenimo pojam identiteta s pojmom povezanih predmeta (T 254).

Pod »osjećajem« se, dakle, misli upravo na taj glatki prijelaz u kojem nema neke rupe u slijedu naših percepcija. Tako dobivamo novi izraz: lanac preklapajućih percepcija. U tom slučaju to bi značilo, a vjerojatno je slično mislio i Hume, da glatki prijelaz uma s jednog predmeta na drugi znači kako jedna percepcija zauzima mjesto druge kada ta počne blijedjeti, ali još uvijek nije potpuno nestala. Neka treća percepcija mijenja njezino mjesto na isti način, i tako do kraja samog lanca, a sve to nepojmljivom brzinom. Upravo na taj način se zavaramo i povjerujemo $\mathrm{u}$ »neprekinuto postojanje percepcija naših osjeta, da bismo uklonili taj [ustvari postojeći] prekid te nailazimo na pojam duše, jastva i supstancije, kako bismo prikrili promjenu« (T 254).

Međutim, Hume je svjestan da, želi li dokazati kako je jastvo tek iluzija koja se stvara kada sukcesiju povezanih predmeta zamijenimo identitetom, mora najprije pokazati da se svi predmeti kojima pripisujemo identitet, ukoliko ne možemo jasno opažati njihovu nepromijenjenost i neprekinutost, ustvari sastoje od sukcesije povezanih, ali različitih, predmeta ( $\mathrm{T}$ 254). Zamislimo bilo koju masu materije, iziskuje od nas Hume, čiji su dijelovi neprekinuti i spojeni te ćemo joj pripisati savršeni identitet ako svi njezini dijelovi ne bivaju promijenjeni ili na neki način prekinuti tijekom promjene mjesta ili prolaza vremena. Zamislimo, također, da je najmanji mogući dio dodan ili oduzet toj masi, i identitet te iste mase bit će, u strogom smislu, uništen. No, prijelaz misli od predmeta koji je postojao prije promjene do predmeta koji postoji nakon nje toliko je gladak da ga rijetko i primjećujemo, zbog čega vrlo lako umišljamo da je riječ o neprekinutoj opservaciji jednog te istog predmeta (T 255-256). To je slučaj sa svim predmetima koji doživljavaju promjene. Očito i najmanja promjena za Humea predstavlja uništenje identiteta. To nije iznenađujuće s obzirom na njegovu radikalnu primjenu empirističih načela. Naime, ako je sve što možemo spoznati dobiveno, posredno ili neposredno, putem osjetila, tada ne možemo spoznati stvarnosti poput, primjerice, supstancije i jastva, a u skladu s time zaključujemo da iste ne postoje. Bez jednostavne impresije nema jednostavne ideje, a sve što ostaje je svežanj povezanih percepcija, čija najmanja kvalitativna promjena mijenja identitet samog svežnja. Konačno, Hume zaključuje da je neprekinuti 
progres mišljenja taj koji stvara identitet (što naziva nesavršenim identitetom), a ne stvarna neprekinutost i nepromijenjenost predmeta opservacije (T 256).

Nakon svega, preostaje razmotriti relacije pomoću kojih se stvara dojam jedinstva uma ili misleće osobe. To su, za Humea, relacije kontinuiteta, sličnosti i uzročnosti. Kontinuitet je na neki način već spomenut ukazivanjem na glatke prijelaze naših percepcija, pri čemu ostaju relacije sličnosti i uzročnosti među našim prošlim i sadašnjim percepcijama. Počnimo s relacijom sličnosti. Pretpostavimo, kaže Hume, da možemo zadržavati većinu svojih sjećanja (memorija), i vrlo lako ćemo pripisati neku relaciju među različitim varijacijama naših percepcija, kako one sukcesivno slijede. Riječ je, kao prvo, o relaciji sličnosti među tim percepcijama, a na temelju te sličnosti koja se javlja u našoj memoriji imaginacija još lakše čini onaj glatki prijelaz s jedne percepcije na drugu te čitava cjelina naših sjećanja izgleda poput neprekinutog postojanja jednog predmeta ( $\mathrm{T}$ 260-261). O tome svjedoči i sljedeća Humeova rečenica: »U tom slučaju, stoga, memorija ne samo da otkriva identitet, nego sudjeluje u njegovu proizvođenju, i to stvaranjem relacije sličnosti među percepcijama« (T 261).

Ta Humeova rečenica apelira na cirkularnost tzv. memorijskog kriterija osobnog identiteta. Njime se, naime, preko stvaranja relacije sličnosti među našim prošlim percepcijama stvara (iako ne u potpunosti) osobni identitet (ili barem njegova iluzija), umjesto da služi strogo kao kriterij prepoznavanja istog. Hume time stvara entitet čije bi postojanje trebao dokazati, pri čemu valja zaključiti da je ideja ljudskog uma, kao jednostavnog i tijekom vremena identičnog predmeta, fiktivna.

Što se tiče uzročno-posljedičnih odnosa među našim percepcijama, važno je upozoriti na to da je Hume čovjekov um razumijevao kao sustav različitih percepcija koje su povezane relacijom između uzroka i učinka te koje se međusobno proizvode, uništavaju, utječu i mijenjaju (T 261). Ne bismo li tu mogli ustanoviti da upravo neko jastvo omogućuje takvu povezanost? Odgovor je negativan, zato što nema potrebe za uvođenjem takvog identiteta kada se odnos percepcija može objasniti drugačije. Hume ilustrira uzročne veze u ljudskom umu uspoređujući ih s odnosima osoba i institucija u državi:

U tom pogledu, ne mogu preciznije usporediti dušu ni s čime kao s republikom ili federacijom, u kojima je nekolicina članova ujedinjena recipročnim vezama vladanja i subordinacije te stvaraju druge osobe, koje tada propagiraju istu republiku u neprekidnim promjenama njezinih dijelova (T 261).

Iz tog citata proizlazi da je osobni identitet sličniji identitetu koji posjeduje neka država, a ta ista država, iako na neki način jest jedna i identična sebi kroz vrijeme, ne posjeduje savršeni identitet kakav bi imao neki jednostavan predmet. Hume je, naime, tvrdio da uzročno-posljedične relacije naših percepcija nisu dovoljne za to da bismo među njima pronašli neku jednostavnu impresiju koja bi bila upravo impresija jastva (duha ili duše), ali vidimo da iste relacije mogu također dovesti do stvaranja iluzije o postojanju savršenog identiteta ljudske osobe (T 254). 
Na temelju tih dviju relacija, dakle sličnosti i uzročnosti, vidimo da je uloga memorije u stvaranju ideje osobnog identiteta središnja. Bez memorije, bila ona savršena ili ne, ne bismo imali nikakvu ideju uzročno-posljedične veze i sličnosti među percepcijama (T 262). No, ideja osobnog identiteta koja može biti izvedena iz naše memorije nije ideja savršeno jednostavnog i identičnog predmeta, nego složena ideja dobivena na temelju brojnih impresija. Hume smatra da je time dokazao svoj stav, jer je ujedno:

1. pokazao nemogućnost (ispravnog) stvaranja jednostavne ideje jastva;

2. pokazao kako dolazi do stvaranja lažne jednostavne ideje jastva;

3. ponudio tumačenje osobnog identiteta prema kojemu on nije jednostavan i savršen, pri čemu je pridijevanje identiteta više gramatička konvencija nego iskazivanje neke znanstvene i filozofske istine.

Zaključno ovom poglavlju, možemo Humeovim riječima napraviti rezime njegovih misli o osobnom identitetu:

Identitet ovisi o relaciji ideja, a te relacije proizvode identitet, i to putem onog glatkog prijelaza koji omogućuju. No, budući da te relacije i lakoća tih prijelaza mogu biti umanjene tek neosjetno, nemamo ispravnog standarda kojim bismo riješili ijednu raspravu o trenutku u kojem one [naše ideje] stječu ili gube pravo na ime identiteta (T 262).

Dakle, osobni identitet je za Humea zagonetka, i to zagonetka koju ne možemo ispravno odgonetnuti, jer u našem iskustvu nije pružen neki standard, neki kriterij kojim bi ona bila konkluzivno odgonetnuta. Utoliko se moramo suzdržati od pozitivnih tvrdnji o istome, jer ćemo svim daljnjim tvrdnjama koje iz njih proizlaze samo škoditi filozofskim nastojanjima. Objašnjenje osobnog identiteta za Humea mora biti, ako je ono uopće moguće, naturalističko.

\section{Humeovi komentatori}

Prije nego što krenemo s izlaganjem misli pojedinačnih Humeovih komentatora, trebalo bi reći da bi njihov popis mogao biti širi i drugačiji. No, postojeći popis omogućuje nam istaknuti važne aspekte iz kojih možemo promatrati razvoj Humeove misli, jer obrađuju Humeov ili „humeovski“ pristup pojmu supstancije te razmatraju nekoliko problema u Humeovim argumentima. Popisu komentatora potrebno je dodati i samog Humea. Naime, Humeova Rasprava sadržava tzv. Dodatak, u kojem je Hume ponovo ukratko razmotrio neke od problema o kojima se očitovao u Raspravi. Govoreći ponovo o problemu osobnog identiteta, otkrio je da nije siguran u rješenja koja je ponudio te da mu se čini kako je od cijele stvari napravio labirint iz kojeg se ne može izvući (A 633). Dodatne komentatore i nesigurnost koju Hume objašnjava u kasnijem dijelu Rasprave navodimo ovdje kako bismo Humeovu teoriju suočili s tri kritička pitanja koja su bitna za bolje razumijevanje problema, ali i koja predstavljaju ozbiljan izazov za istu teoriju. Najprije možemo pitati, ako percepcijama nije potreban neki supstrat, znači li to 
da je svaka percepcija zasebna supstancija? Zatim možemo pitati, je li Humeov argument cirkularan, s obzirom na to da se njegova teorija vjerovanja može interpretirati tako da vjerovanja koje pojedinci drže ipak zahtijevaju supstanciju? Konačno možemo pitati, ako ideja povezanosti percepcija nije utemeljena u iskustvu, je li moguće tvrditi da osobu čine povezane percepcije?

\subsection{Barry Stroud i nepotrebnost supstancije}

U prethodnom dijelu teksta bilo je govora o tome da ideja jastva ili duše ne odgovara empirističkim načelima na temelju kojih Hume filozofira. O tome je potrebno reći nešto više, a upravo je Barry Stroud precizno izdvojio dijelove Rasprave u kojima Hume pripravlja tlo za takvu tvrdnju te ih komentirao. Kao prvo, Hume primjećuje da je inklinacija prema stvaranju nečega što u stalnim promjenama ostaje nepromijenjeno, a istovremeno nedostupno osjetilima, potpuno prirodna. Takav entitet filozofi nazivaju supstancijom ili, u slučaju osoba, jastvom ili dušom (T 219). Tako je sukob između identiteta i različitosti naizgled riješen. Barry Stroud komentira:

Sve čega smo svjesni - protoka percepcija — promjenjivo je i isprekidano; ali vjeruje se da postoji nešto drugo - supstancija — što ostaje nepromijenjeno i neprekinuto tijekom tih promjena. „Akcidenti“ koji „pripadaju“ supstanciji se mijenjaju, dok supstancija ostaje jedna i ista (Stroud, 2003, 120).

No, Hume ne vjeruje u supstanciju. Štoviše, smatra je potpuno suvišnom. Identitet u različitosti koji filozofi traže ne postoji, a odnosi onog što dobivamo iskustvom mogu se lako objasniti relacijama kontinuiteta, sličnosti i uzročnosti koje smo prethodno spominjali.

Osim toga, Hume pojam supstancije smatra ne-inteligibilnim, jer od nas traži da formiramo ideju koja se ne može formirati. Supstanciju nikada ne surećemo $\mathrm{u}$ iskustvu, a jedini način da sebi nešto predočimo je posredstvom ideja koje smo dobili u iskustvu (Stroud, 2003, 120). Također, supstancija je definirana kao nešto što može postojati samo po sebi. Nažalost, ako se obratimo našemu iskustvu, ta definicija ne koristi nam ni na koji način da razlikujemo između supstancije i naših percepcija, jer svaka, tvrdi Stroud »odjelita stvar odvojiva je u imaginaciji od svake druge stvari. Što god je moguce u imaginaciji je moguce [naprosto], tako da svaka naša percepcija može postojati odvojeno od svih ostalih te ne potrebuje ništa drugo što bi podržavalo njezino postojanje« (Stroud, 2003, 120). Kao što vidimo iz Stroudove primjedbe, postojanje bilo koje od naših percepcija na istom je stupnju metafizičke ljestvice na kojem bi bilo i postojanje supstancije, kada bi ona postojala. Ne bismo smjeli na temelju te tvrdnje misliti da je za Humea svaka percepcija ujedno i supstancija, nego to da ne vidi nikakve koristi u tradicionalnom razlikovanju između supstancije i akcidenta te kako nam to razlikovanje ni na koji način ne pomaže da pojam supstancije učinimo inteligibilnim (Stroud, 2003, 121). Konačno, pojam supstancije nije nam potreban da objasnimo kako predmetima pridijevamo identitet. U tom slučaju Stroudovo objašnjenje je više- 
manje jednako onom koje je izloženo u prethodnom poglavlju te ćemo se zadovoljiti s tih nekoliko uvida u Humeovu filozofiju koje nam je pružio.

\subsection{John Ivan Biro i izbjegavanje cirkularnosti}

John Ivan Biro bavi se jednim od pitanja vezanih uz Humeovu teoriju osobnog identiteta. Riječ je o jednoj od osnovnih poteškoća njegove teorije, a koju on nije uočio. Hume umu (ili katkad imaginaciji) pripisuje određene aktivnosti za koje tvrdi da generiraju vjerovanje u sam um ili jastvo kojem bi trebale pripadati. Hume tako govori o, primjerice, opserviranju, zamjećivanju, asociranju i vjerovanju kao činima koje um treba izvesti da bismo na empiristički prihvatljiv način mogli objasniti način kojim ideja jastva nastaje. Čini se da pri tome Hume već pretpostavlja postojanje jastva i naše ideje istog, tj. da njegova teorija vjerovanja pretpostavlja jedan neprekinuto postojeći entitet (Biro, 1979, 45). Kako onda pokazati da je naše vjerovanje u takav entitet vjerovanje u nešto fiktivno? Biro smatra da se Hume može obraniti od takve kritike te da je cirkularnost koja se njegovoj teoriji pripisuje u tom slučaju samo privid (Biro, 1979, 45). Taj privid, naime, nastaje iz dva razloga:

1. U različitim dijelovima Rasprave Humea zanimaju različite stvari, što se zrcali u jeziku koji u tim dijelovima koristi te se stvara dojam da pretpostavlja neko nepromijenjeno jastvo;

2. Hume nije dovoljno istaknuo svoje razlikovanje između savršenog i nesavršenog identiteta, zbog čega se iz vida gubi da je zanijekao samo prethodnu vrstu identiteta, a potonju je objasnio u okvirima vlastitog empirizma (Biro, 1979, 46).

Status jastva kao fiktivnog entiteta u tom slučaju ipak ne bi bio apsurdan, a cirkularnost bi bila izbjegnuta, jer vjerovanja (opservacije, asociranje i dr.) ne bi pretpostavljala onu vrstu osobnog identiteta kojoj Hume negira postojanje.

Da bismo jasnije izložili i potkrijepili dano objašnjenje, na temelju Humeova nauka o asocijaciji (tj. vezi, spajanju i interakciji) ideja, moramo ustanoviti sljedeće:

1. pretpostavlja li Humeova teorija vjerovanja nekog zasebnog čimbenika (jastvo) koji uzrokuje različite vrste asocijacijskih čina ili

2. predmeti koji sudjeluju u asocijaciji (a to su percepcije) sami izvode te čine (Biro, 1979, 46-47).

Ukratko, pitanje koje se postavlja je: koji model asocijacije je temeljan u Humeovu nauku? Nedvojbeno je da Hume u raspravi govori katkad o umu i/ili imaginaciji kao o onoj koja „asocira percepcije“, kao o onoj koja „zamjećuje“, „opservira“ i razvija „običaje“ i „navike“. S druge strane, govori o impresijama i idejama koje se same međusobno „privlače“ te tako stvaraju kompleksnije ideje i impresije. Je li Hume, stoga, obvezan na dva različita modela asocijacije?

»Čini mi se da ne, ako se prisjetimo da je srce Humeove teorije jastva upravo tvrdnja da um nije ništa više doli skupine percepcija (organiziranih na određen 
način). Tada, zasigurno, lokucije poput 'um asocira' ne mogu biti uzete u njihovoj nominalnoj vrijednosti« (Biro, 1979, 47).

Izgleda da je cirkularnost time izbjegnuta. I zaista, kada čitamo paragrafe u kojima Hume govori o umu kao o onome koji asocira percepcije, trebamo samo imati u vidu da on taj um izričito definira kao skupinu percepcija. U Humeovu smislu bi, dakle, bilo isto reći da um nešto čini i da percepcije same nešto čine, jer su čini percepcija čini uma. ${ }^{5}$

\subsection{David Hume kao vlastiti komentator}

Vratimo se za kraj Davidu Humeu, koji je napisao kratki komentar na svoje poglavlje o osobnom identitetu u Dodatku svoje Rasprave. Iako i dalje smatra da um nije više od svežnja percepcija, nakon ponovnog čitanja svojih tvrdnji kaže da se našao umiješanim u takav labirint da nije više siguran kako bi prepravio svoje mišljenje ili ga učinio konzistentnim (A 633). Što se tiče prepravljanja ili mijenjanja vlastita mišljenja, Hume ne zna što činiti, jer je uvjeren da je svoje premise izvukao iz iskustva te da su njegovi zaključci posredno ili neposredno izvučeni iz tog istog iskustva. Što se tiče pokušaja da se čitavo rješenje koje nudi učini konzistentnim, javlja se nekoliko problema. Naime, Hume vjeruje da svaka percepcija (ili predmet koji ona u umu predstavlja) posjeduje zasebnu egzistenciju. Kada su povezane, takve percepcije čine ono što nazivamo osobom. Ali ljudski razum nije u stanju otkriti veze koje postoje među tim različitim percepcijama. Povezanost između različitih percepcija možemo jedino osjetiti. Kada reflektiramo o slijedu prošlih percepcija od kojih je sazdan um, na neki način osjećamo da su povezane (A 635). Međutim, ne možemo opažati tu povezanost, isto kao što ne možemo opažati uzročnost bilo koje vrste. Iako to izričito nije rekao na tom mjestu, mogli bismo reći da Hume ne može objasniti na koji su način percepcije povezane, jer ideja povezanosti o kojoj ovdje govorimo nije izvedena iz neke impresije povezanosti. Stoga je i ta povezanost u opasnosti da bude proglašena fiktivnim entitetom. Ono što Humeu nedostaje u promišljanjima o osobnom identitetu je, kako ističe, objašnjenje načelā koja ujedinjuju sukcesivne percepcije u našim mislima (A 636).

Ukratko, riječ je o dvama načelima koja se čine nekonzistentnima, a koja Hume ne može poreći: 1 . da sve naše zasebne percepcije posjeduju zaseban temelj egzistencije, tj. da jesu zasebne egzistencije; 2 . da um nikada ne percipira neku stvarnu povezanost među različitim egzistencijama (A 636).

Kada bi sve naše percepcije pripadale nekomu jednostavnomu entitetu, ili kada bi um mogao percipirati neku stvarnu povezanost među njima, taj problem ne bi postojao. Na Humeovu žalost, to nije slučaj. Sve što nam ostaje je spomenuti osjećaj koji nastaje kada promatramo sukcesiju naših prošlih percepcija. Konačno, Hume kaže da je problem možda rješiv te kako bi ga netko drugi ili on nakon dužeg promišljanja mogao riješiti, no opći zaključak koji donosi ipak

5 Riječ je, stoga, o redukcionističkom pristupu, u kojem se um u potpunosti svodi (reducira) na percepcije. 
je skeptičke naravi te rezignirano tvrdi da je ta poteškoća prevelika za njegov razum (A 633).

\section{Zaključak}

Humeova problematizacija osobnog identiteta, njegova skepsa o metafizičkom temelju ideja supstancije i jastva, ostala je predmetom rasprave u metafizici i filozofiji uma do naših dana. No, iako ga se često spominje kao najdosljednijeg filozofa empirističke tradicije, među predstavnicima njegova intelektualnog potomstva nailazimo na tragove kritike njegove misli o osobnom identitetu. Posebno su u radu istaknuti radovi dvojice eminentnih poznavatelja Humeova djela u 20. stoljeću, koji se i dalje smatraju mjerodavnima.

Najprije je spomenut rad Barryja Strouda, u kojem autor tvrdi da percepcije ne moramo shvatiti kao supstancije (ili kao da svaka ima vlastitu supstanciju), jer Hume odbacuje tradicionalno razlikovanje supstancije i akcidenta. Problematično je, međutim, u Stroudovoj obrani što Hume tvrdi (A 636) da sve naše percepcije imaju zaseban temelj egzistencije. Međutim, ne nailazimo ni u Humea ni u Strouda na argument kojim bi se opravdala pretpostavka zasebnog temelja za svaku percepciju, jer se takav temelj također ne pojavljuje u iskustvu.

Nakon toga je spomenut rad J. I. Biroa, u kojem autor nastoji pokazati da Humeova teorija vjerovanja ne pretpostavlja postojanje supstancije kao metafizičkog supstrata kojemu vjerovanja pripadaju. Međutim, obrana koju nudi Biro u opasnosti je da je se protumači kao pokušaj djelomično samovoljnog interpretiranja Humeove misli, zbog pretpostavke da je Hume implicitno imao na umu misli koje nije izravno objasnio. U najboljem slučaju, to znači da unatoč intelektualnoj veličini Rasprave o ljudskoj naravi, Humeovi argumenti sadržavaju potencijalno nerazrješive unutarnje nedosljednosti.

Na kraju su spomenuti dijelovi Humeova Dodatka, u kojima izražava bojazan zbog činjenice da ideja povezanosti percepcija nije utemeljena u nekoj impresiji. To predstavlja ozbiljan problem. Naime, svrha djela pod naslovom Rasprava o ljudskoj naravi može biti samo u pokušaju odgovora na pitanje: »Što je čovjek? « Ako je Humeov odgovor to da je čovjek skup povezanih percepcija, onda je važno objasniti narav te povezanosti. Ako povezanost nije moguće objasniti zato što ideja povezanosti nema iskustveni temelj, onda Humeov odgovor na pitanje o čovjeku nije u skladu s empirističkim načelima koja zagovara. Konačno, Humeu nije preostalo tvrditi drugo nego da povezanost možemo jedino osjetiti.

\section{Literatura:}

Berkeley, George (2003). A Treatise Concerning the Principles of Human Knowledge. Mineola NY: Dover Publications.

Biro, John Ivan (1979). Hume's Difficulties with the Self. Hume Studies, 5, 1, 45-54.

Hume, David (1978). A Treatise of Human Nature. Oxford: Clarendon Press. 
Locke, John (1995). An Essay Concerning Human Understanding. New York: Prometheus Books.

Russell, Bertrand (2005). Mudrost zapada. Split: Marijan tisak.

Stroud, Barry (2003). Hume. London — New York: Routledge.

The Problem of Personal Identity in the Philosophy of David Hume

Stipe Buzar*

\section{Summary}

The theme of the essay is the problem of personal identity in the philosophy of David Hume. Firstly, the text presents elements of Hume's theory of ideas which are required so as to provide the context for an understanding of his treatment of the issue of personal identity.

The second section describes Hume's approach to personal identity with reference to the pertinent chapter from Hume's A Treatise of Human Nature. Next, the views of some of the most quoted of Hume's commentators are offered in order to broaden our understanding of certain aspects of Hume's problem and demonstrate some shortcomings in his approach.

Key words: David Hume, personal identity, empiricism, perception, impression, ideas, substance

* Stipe Buzar, Ph.D., DIU LIBERTAS International University. Address: Trg J. F. Kennedyja 6b, 10000 Zagreb, Croatia. E-mail: sbuzar@libertas.hr 